\title{
In silico and experimental analyses predict the therapeutic value of an EZH2 inhibitor GSK343 against hepatocellular carcinoma through the induction of metallothionein genes
}

\author{
Tsang-Pai Liu1,2,3,4,5, Yi-Han Hong ${ }^{2}$, Kwang-Yi Tung ${ }^{2}$ and Pei-Ming Yang ${ }^{1}$ \\ 1 The Ph.D. Program for Cancer Biology and Drug Discovery, College of Medical Science and Technology, Taipei Medical \\ University, Taipei, Taiwan \\ 2 Department of Surgery, Mackay Memorial Hospital, Taipei, Taiwan \\ ${ }^{3}$ Mackay Junior College of Medicine, Nursing and Management, New Taipei City, Taiwan \\ ${ }^{4}$ Department of Medicine, Mackay Medical College, New Taipei City, Taiwan \\ ${ }^{5}$ Liver Medical Center, Mackay Memorial Hospital, Taipei, Taiwan \\ Correspondence to: Pei-Ming Yang, email: yangpm@tmu.edu.tw
}

Keywords: EZH2, metallothionein, hepatocellular carcinoma, microarray analysis, therapeutic biomarker

Received: December 31,2015 Accepted: January 22, $2016 \quad$ Published: January 29, 2016

This is an open-access article distributed under the terms of the Creative Commons Attribution License, which permits unrestricted use, distribution, and reproduction in any medium, provided the original author and source are credited.

\section{ABSTRACT}

There are currently no effective molecular targeted therapies for hepatocellular carcinoma (HCC), the third leading cause of cancer-related death worldwide. Enhancer of zeste homolog 2 (EZH2), a histone H3 lysine 27 (H3K27)-specific methyltransferase, has been emerged as novel anticancer target. Our previous study has demonstrated that GSK343, an S-adenosyl-L-methionine (SAM)-competitive inhibitor of EZH2, induces autophagy and enhances drug sensitivity in cancer cells including HCC. In this study, an in silico study was performed and found that EZH2 was overexpressed in cancerous tissues of HCC patients at both gene and protein levels. Microarray analysis and in vitro experiments indicated that the anti-HCC activity of GSK343 was associated with the induction of metallothionein (MT) genes. In addition, the negative association of EZH2 and MT1/MT2A genes in cancer cell lines and tissues was found in public gene expression database. Taken together, our findings suggest that EZH2 inhibitors could be a good therapeutic option for HCC, and induction of MT genes was associated with the anti-HCC activity of EZH2 inhibitors.

\section{INTRODUCTION}

Surgical resection and liver transplantation are the main curative treatments for hepatocellular carcinoma (HCC); however, only 15 to $25 \%$ of patients are suitable for these treatments [1]. In addition, HCC is relatively chemo-resistant and highly refractory to cytotoxic chemotherapy, and there is currently no reliable and effective therapy for patients with advanced or metastatic disease [1]. Therefore, HCC is still the third leading cause of cancer-related death worldwide [2]. Molecular targeted agents have been regarded as new treatment option. The multi-kinase inhibitor, sorafenib, has been approved for treating advanced HCC in 2007 [3]. However, sorafenib monotherapy seems insufficient to reach satisfactory results in $\mathrm{HCC}$ patients because it confers less than 3 months of actual survival gain in both Western and Asian populations [3, 4]. Therefore, it is still urgent to develop an effective therapeutic strategy for HCC.

Ehancer of zeste homolog 2 (EZH2) is a histone $\mathrm{H} 3$ lysine 27 (H3K27)-specific methyltransferase, mediating mono-, di- and tri-methylation at histone H3K27 (H3K27-me1/2/3) together with its interacting partners SUZ12 and EED. EZH2 is frequently overexpressed in tumors [5-7], and inhibition of EZH2 serves as potential anticancer treatments $[8,9]$. Several potent EZH2 inhibitors have been developed in recent years [10]. For example, 3-Deazaneplanocin A (DZNep), a S-adenosyl$L$-homocysteine (SAH) hydrolase inhibitor, indirectly inhibits EZH2 through the depletion of EZH2 protein and the associated H3K27-me3 [9]. One of the major class of EZH2 inhibitors belongs to the competitive 
inhibitors of S-adenosyl- $L$-methionine (SAM) that is a universal methyl donor for the catalytic reaction of histone methyltransferases. Several SAM-competitive inhibitors, such as EPZ005687, EI1, GSK126, and GSK343, are developed and can selectively kill lymphoma cells with EZH2-activating mutations [11-14].

Based on the in silico and in vitro analyses of this study, we found that EZH2 is overexpressed in HCC and may be an attractive molecular target for treating HCC. An EZH2 inhibitor, GSK343, acted as a potent anti-HCC agent. Microarray gene expression profiling showed the induction of metallothionein (MT) genes by GSK343, which was associated with its anticancer activity. In addition, negative association of EZH2 and MT1/MT2A expression was observed. Our study provides a novel aspect of EZH2 inhibitors for treating HCC.

\section{RESULTS AND DISCUSSION}

\section{Identification of EZH2 as a therapeutic target for HCC treatment}

To identify possible candidate genes essential for HCC pathogenesis, we analyzed gene expression profiles between normal and tumor liver tissues from three published microarray datasets [15-17]. The results found that 13 genes are upregulated in tumor tissues in these datasets (Figure 1A and Table 1). Their functional association was analyzed by the GeneMANIA (http:// genemania.org/) [18]. Most of them are associated with cell cycle regulation (as marked by red color in Table 1), suggesting that HCC may be resulted from dysregulation of cell cycle. In addition, several genes have been reported to correlate with HCC pathogenesis, For example, deregulation of E2F1 has been implicated in the development of HCC [19]. TOP2A overexpression in HCC correlates with shorter patient survival and chemoresistance [20]. Pathway analysis showed the relationship between EZH2 and other genes in a direct or indirect manner (Figure 1B), implying EZH2 may have similar function with these genes. Indeed, EZH2 has been linked to cell cycle machinery through cyclin-dependent kinases 1/2 (CDK1/2)-dependent phosphorylation at Thr350. Blockage of Thr350 phosphorylation reduces EZH2-mediated cell proliferation and migration [21]. Therefore, we proposed that $\mathrm{EZH} 2$ may also participate in HCC pathogenesis. Consistently, recent studies have shown that EZH2 plays an important role in HCC tumorigenesis [22-24]. Overexpression of EZH2 is frequently detected in HCC tissues, which was correlated with the aggressiveness and poor prognosis [36-38]. Knockdown of EZH2 expression in HCC cells can reverse tumorigenicity in a nude mouse model [25], demonstrating the potential therapeutic value of $\mathrm{EZH} 2$ inhibition in $\mathrm{HCC}$.

\section{Overexpression of EZH2 in HCC tissues}

To confirm the relationship of EZH2 and $\mathrm{HCC}$ pathogenesis, we analyzed EZH2 expression profiles using existing cDNA microarray datasets deposited in the Oncomine database (http://www.oncomine.org/) [26]. In three microarray datasets having both HCC and normal liver tissues [27-29], significantly increased EZH2 gene copy number and mRNA expression in HCC compared with normal liver tissues were found (Figures 2A-2C). In addition, Wurmbach's dataset also shows the upregulation of EZH2 mRNA in samples from tissues of normal, cirrhosis, dysplasia, to HCC in a stepwise manner (Figure 2D). To investigate whether EZH2 was also overexpressed at protein level, the immunohistochemical staining of EZH2 in normal and cancer tissues was obtained from the Human Protein Atlas (http://www.proteinatlas.org/) that is a public database with millions of immunohistochemical images in 44 different normal human tissues and 20 different cancer types, as well as 46 different human cell lines [30-34]. As shown in Figure 2E, the protein expression of EZH2 was undetectable in normal liver tissues. In liver cancer tissues, however, 6 out of 11 cases are high/medium EZH2 staining and 5 out of 11 cases are low or undetectable. These results suggest that EZH2 is overexpressed in $\mathrm{HCC}$ and may be an attractive molecular target for treating $\mathrm{HCC}$.

\section{GSK343, an EZH2 inhibitor, induces metallothionein (MT) expression that is correlated with its anticancer activity}

Small-molecule-based inhibition of EZH2 has recently been developed as an effective mechanism of therapeutic intervention in hematologic and solid tumors $[12,35]$. Our previous study shows that an activity-based EZH2 inhibitor, GSK343 (Figure 3A), induces autophagy and enhances drug sensitivity in cancer cells including HCC. In this study, we also found that GSK343 inhibited cell viability of a human HCC cell lines, HepG2, in a dose-dependent manner (Figure 3B). To investigate the molecular mechanism involved in the anti-HCC activity of GSK343, microarray analysis was performed and found that 46 gene probes were upregulated and 123 gene probes were downregulated (Supplementary File S1). Top 10 up- and down-regulated gene probes were listed in Table 2. Interestingly, several genes (highlighted in bold) encode metallothionein 1 (MT1) subtypes and MT2 (MT2A) were induced by GSK343. MTs belong a group of cysteine-rich and low-molecular weight intracellular proteins. Due to their rich thiol content, MTs bind many trace metals such as zinc, cadmium, mercury, platinum and silver, thus protecting cells and tissues against heavy metal toxicity [36]. MT1 and MT2 (MT2A), two major isoforms of MT, are found in all types of tissues. Two 
Table 1: The overlapped gene profile that is upregulated in HCC tumor tissues in three published microarray datasets

\begin{tabular}{|l|l|l|l|l|}
\hline $\begin{array}{l}\text { Gene } \\
\text { Symbol }\end{array}$ & Description & $\begin{array}{l}\text { Fold Change } \\
\text { (Chen X et al.) }\end{array}$ & $\begin{array}{l}\text { Fold Change } \\
\text { (Patil MA et al.) }\end{array}$ & $\begin{array}{l}\text { Fold Change } \\
\text { (Chen YL et al.) }\end{array}$ \\
\hline RBM3 & RNA binding motif (RNP1, RRM) protein 3 & 1.569 & 1.563 & 2.246 \\
\hline CPD & carboxypeptidase D & 1.764 & 1.95 & 1.964 \\
\hline CCNA2 & cyclin A2 & 1.991 & 2.685 & 2.4 \\
\hline E2F1 & E2F transcription factor 1 & 3.132 & 2.518 & 3.049 \\
\hline EZH2 & enhancer of zeste homolog 2 (Drosophila) & 1.924 & 1.952 & 2.565 \\
\hline TOP2A & topoisomerase (DNA) II alpha 170kDa & 2.156 & 2.227 & 5.53 \\
\hline MAD2L1 & MAD2 mitotic arrest deficient-like 1 (yeast) & 2.474 & 2.712 & 3.381 \\
\hline NUDT1 & $\begin{array}{l}\text { nudix (nucleoside diphosphate linked moiety X)-type } \\
\text { motif 1 }\end{array}$ & 2.151 & 2.334 & 2.019 \\
\hline FEN1 & flap structure-specific endonuclease 1 & 2.406 & 2.794 & 2.034 \\
\hline RFC4 & replication factor C (activator 1) 4, 37kDa & 2.014 & 2.094 & 2.426 \\
\hline MCM3 & minichromosome maintenance complex component 3 & 1.675 & 1.753 & 2.27 \\
\hline MCM6 & minichromosome maintenance complex component 6 & 1.969 & 1.829 & 2.436 \\
\hline MGAT4A & mannosyl (alpha-1,3-)-glycoprotein beta-1,4-N- & 1.684 & 1.738 & 2.124 \\
\hline
\end{tabular}

EZH2 gene was highlighted in bold and cell cycle-related genes were highlighted in red color.

Table 2: Top 10 up- and down-regulated gene probes in HepG2 cells treated with $10 \mu$ M GSK343 for 6 h

\begin{tabular}{|c|c|c|c|}
\hline Probe ID & Gene Symbol & Description & Fold Change \\
\hline PH_hs_0028852 & MT1B & metallothionein 1B & 4.465048 \\
\hline PH_hs_0006434 & \begin{tabular}{|l|l} 
VPS13C \\
\end{tabular} & vacuolar protein sorting 13 homolog C (S. cerevisiae) & 3.608639 \\
\hline PH_hs_0006739 & TMEM63C & transmembrane protein $63 \mathrm{C}$ & 3.248965 \\
\hline PH_hs_0042917 & MT1M|MT1JP & metallothionein $1 \mathrm{M} \mid$ metallothionein $1 \mathrm{~J}$, pseudogene & 3.151759 \\
\hline PH_hs_0023522 & MMP25 & matrix metallopeptidase 25 & 1.978682 \\
\hline PH_hs_0043618 & LRTOMT & $\begin{array}{l}\text { leucine rich transmembrane and 0-methyltransferase domain } \\
\text { containing }\end{array}$ & 1.926359 \\
\hline PH_hs_0049631 & $\begin{array}{l}\text { MT1IP|MT1X } \\
\mid \text { MT1E|MT1A } \\
\mid \text { MT2A|MT1B } \\
\mid \text { MT1L } \mid \text { MT1H } \\
\end{array}$ & $\begin{array}{l}\text { metallothionein 1I, pseudogene } \mid \text { metallothionein 1X|metallothionein } \\
\text { 1E|metallothionein 1A|metallothionein 2A|metallothionein } \\
\text { 1B|metallothionein 1L (gene/pseudogene)|metallothionein 1H }\end{array}$ & 1.809486 \\
\hline PH_hs_0036496 & TWIST2 & twist basic helix-loop-helix transcription factor 2 & 1.751665 \\
\hline PH_hs_0045784 & MT1A & metallothionein $1 \mathrm{~A}$ & 1.659662 \\
\hline PH_hs_0018184 & MT1X & metallothionein $1 \mathrm{X}$ & 1.651276 \\
\hline PH_hs_0032121 & ARL6 & ADP-ribosylation factor-like 6 & -4.519956 \\
\hline PH_hs_0036082 & HIST1H3J & histone cluster $1, \mathrm{H} 3 \mathrm{j}$ & -3.96339 \\
\hline PH_hs_0042831 & SPINK14 & serine peptidase inhibitor, Kazal type 14 (putative) & -2.858793 \\
\hline PH_hs_0032938 & C16orf47 & chromosome 16 open reading frame 47 & -2.674934 \\
\hline PH_hs_0002738 & PGR & progesterone receptor & -2.653247 \\
\hline PH_hs_0019504 & MZB1 & marginal zone B and B1 cell-specific protein & -2.615926 \\
\hline PH_hs_0031538 & RNASE11 & ribonuclease, RNase A family, 11 (non-active) & -2.606224 \\
\hline PH_hs_0031319 & SLA & Src-like-adaptor & -2.571705 \\
\hline PH_hs_0042528 & OR51Q1 & olfactory receptor, family 51, subfamily Q, member 1 & -2.56117 \\
\hline PH_hs_0045727 & FLT1 & fms-related tyrosine kinase 1 & -2.365311 \\
\hline
\end{tabular}

MT genes were highlighted in bold. 
(A)

Chen et al. $2013 \quad$ Patil et al. 2005

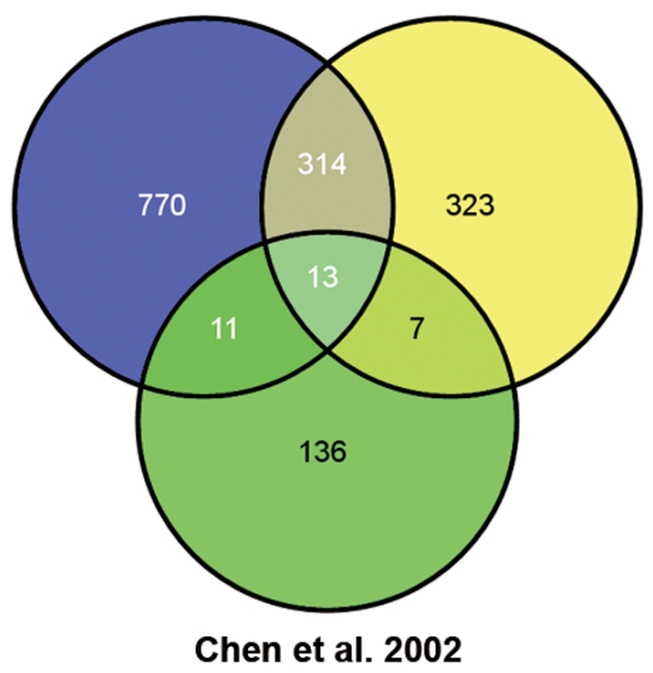

(B)

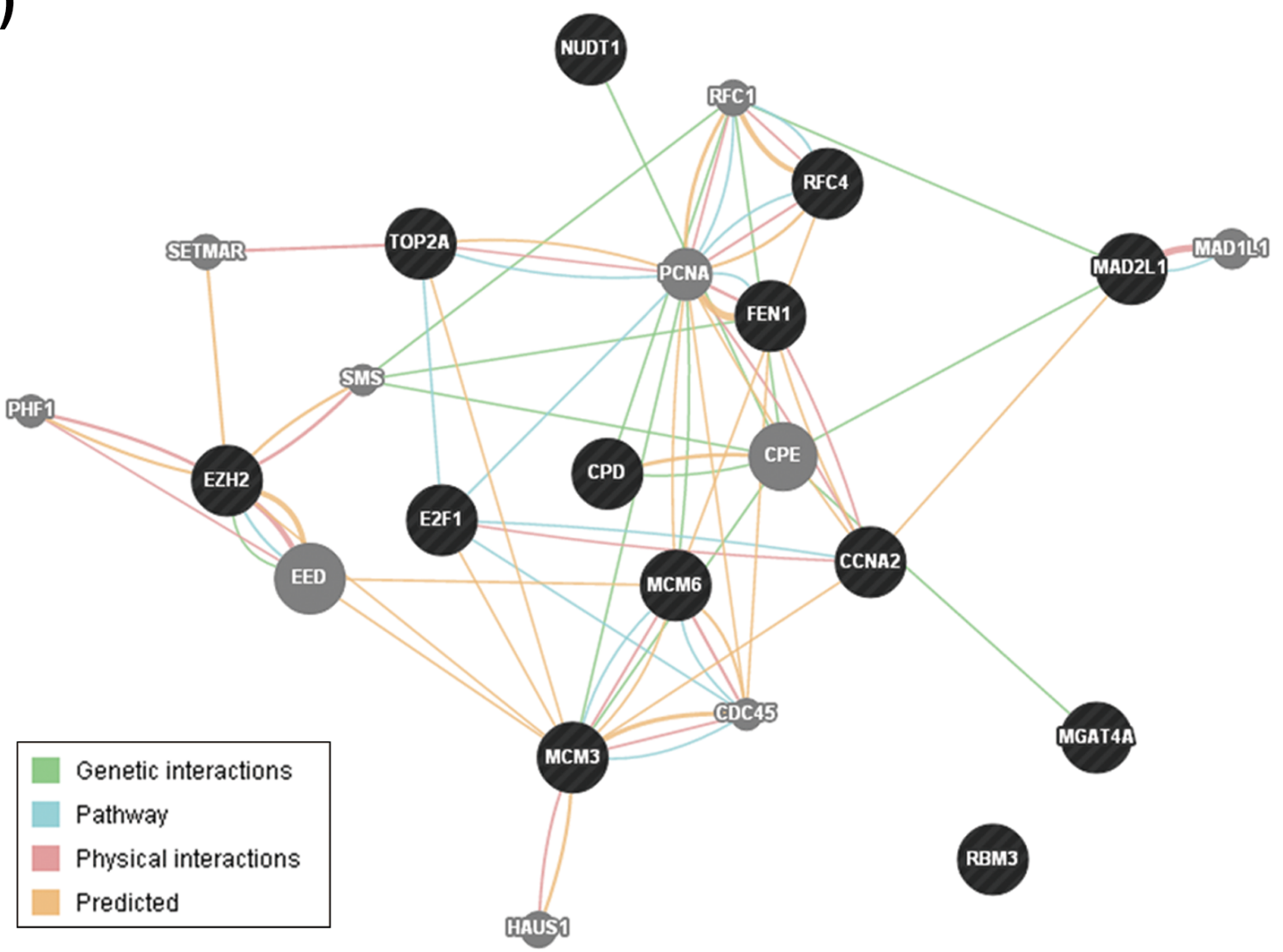

Figure 1: Identification of EZH2 as a potential therapeutic target for HCC treatment. A. The Venn diagram for gene expression profiles between normal and tumor liver tissues from three published microarray datasets. The overlapped genes were shown in Table 1. B. Functional association of the genes in Table 1 was analyzed using the GeneMANIA (http://genemania.org/). The genes in black circles stood for the query genes. The genes in grey circles stood for the genes related to query genes. 
other members, MT3 and MT4, are expressed in specific tissues such as brain [36]. Human MT genes are located on chromosome 16 q13 in a cluster, in which the MT2A, MT3 and MT4 proteins are encoded by a single gene, and the MT1 protein comprises many subtypes encoded by a

(A)

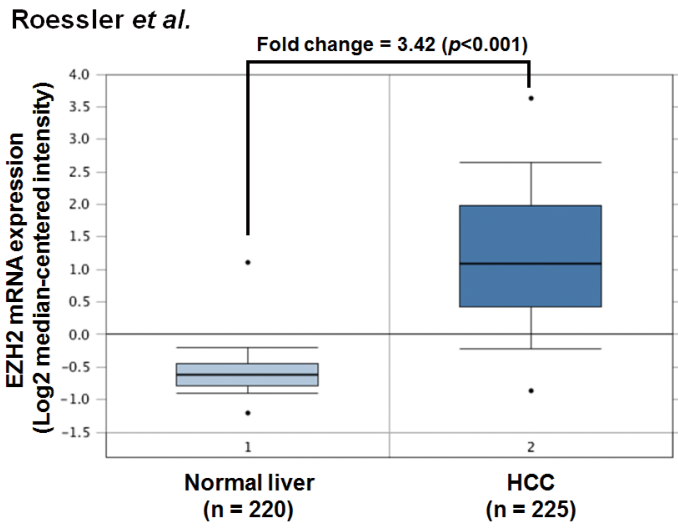

(C)

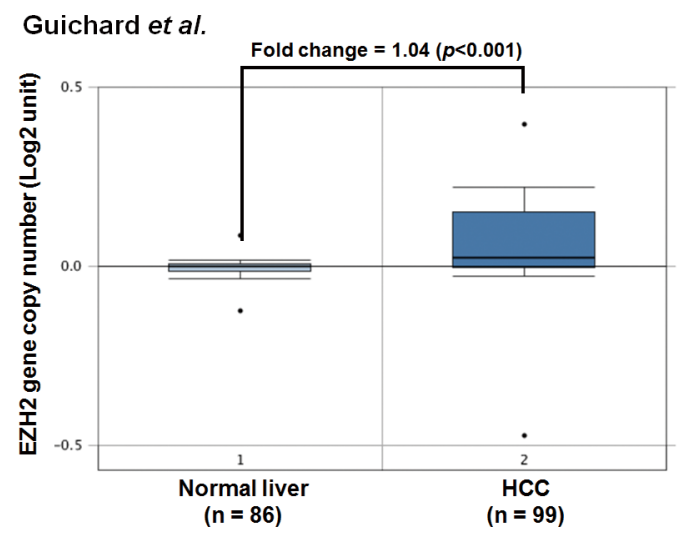

set of MT1 genes. The known functional MT1 subtypes are MT1A, MT1B, MT1E, MT1F, MT1G, MT1H, MT1M, and MT1X, which are believed to play distinct roles, depending on their tissue-specific expression pattern [37]. The mRNA expression of all MT isoforms was examined

(B)

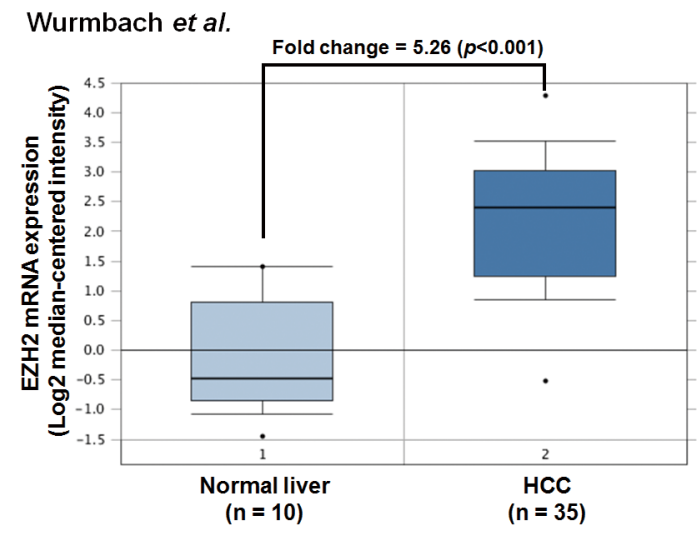

(D)

Wurmbach et al.

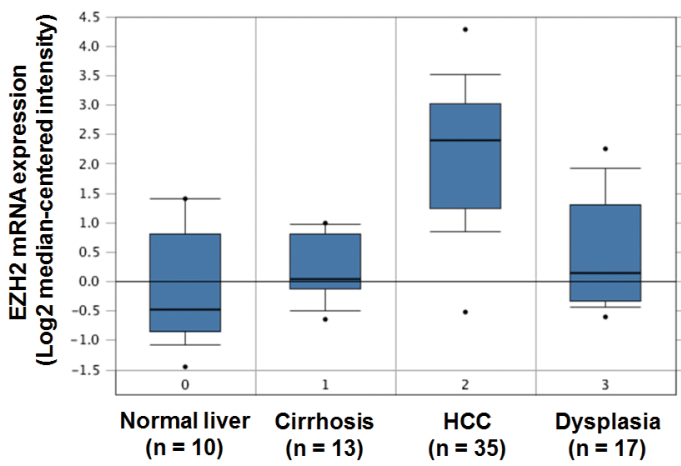

(E)

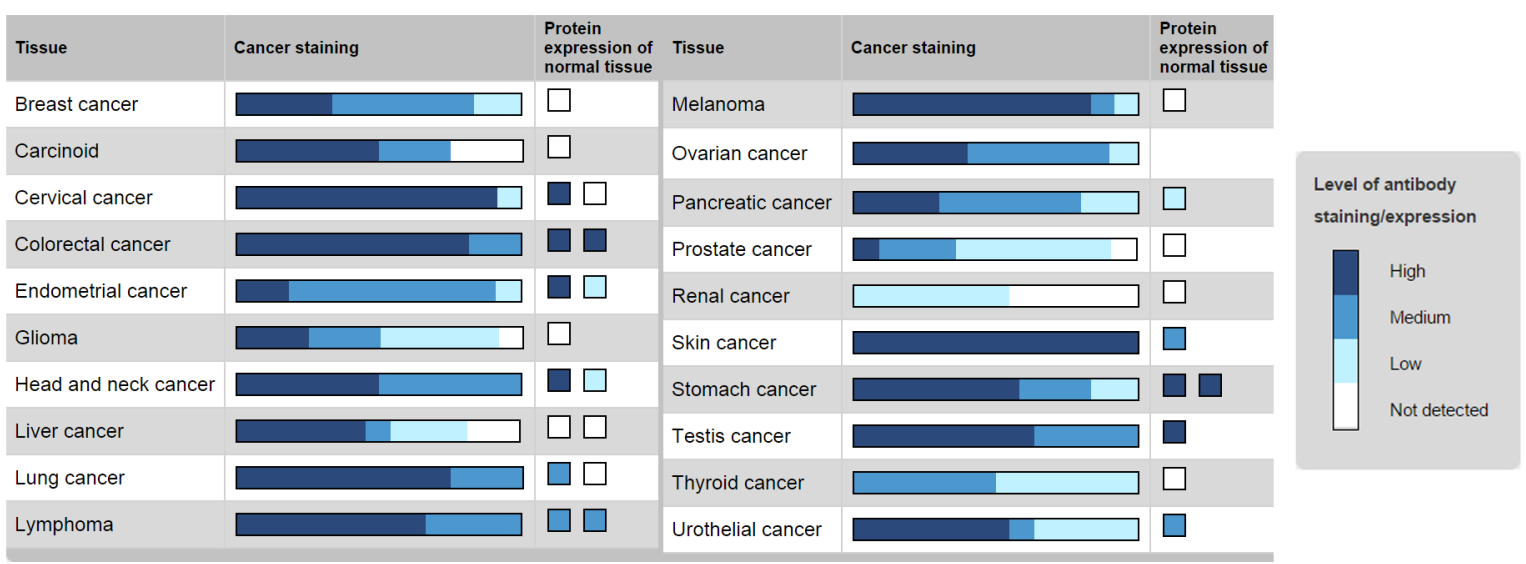

Figure 2: The gene and protein expressions of EZH2 in HCC patients. A.-C. The copy number and mRNA expression of EZH2 in normal liver and tumor tissues. D. EZH2 mRNA expression in tissues of normal, cirrhosis, dysplasia, and HCC patients. Microarray datasets were obtained from the Oncomine database (http://www.oncomine.org/). E. EZH2 protein expression in normal liver and tumor tissues were obtained from the Human Protein Atlas (http://www.proteinatlas.org/). 
(A)

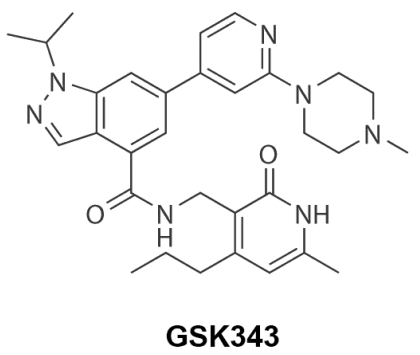

(C)

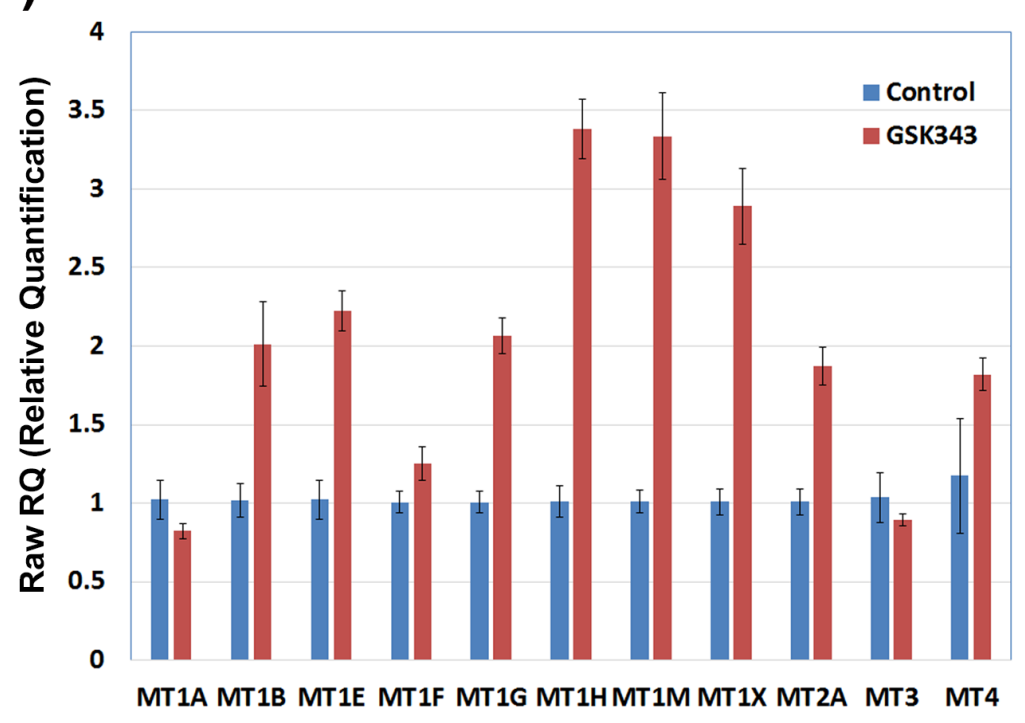

(D)

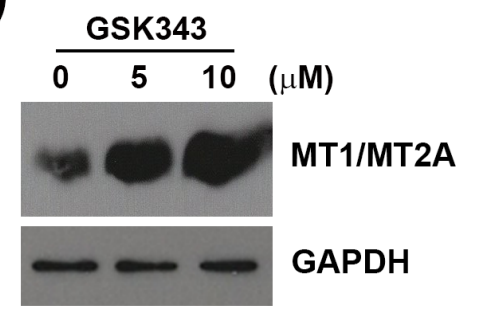

(E)

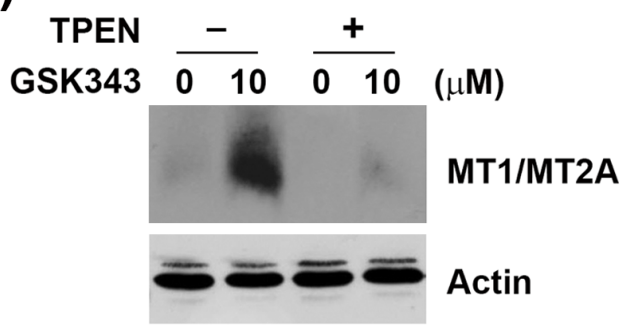

(F)

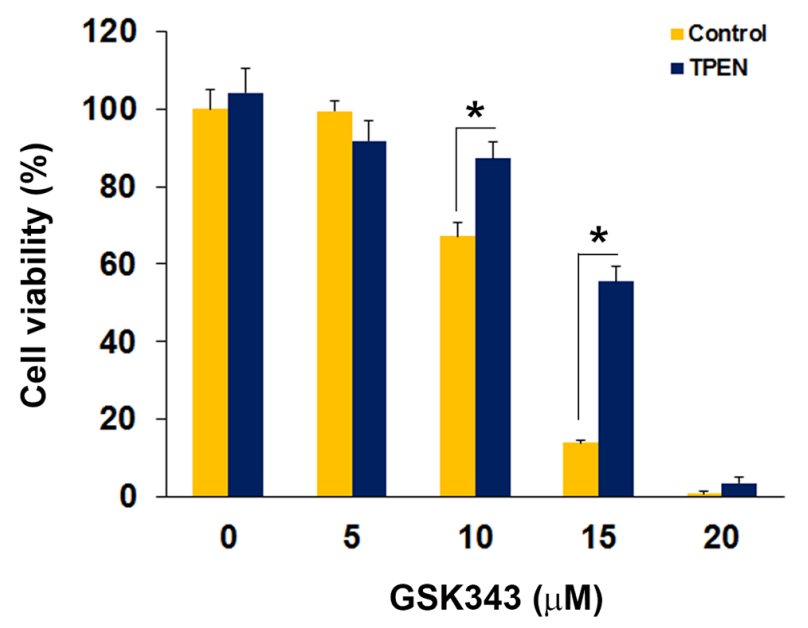

Figure 3: Effect of GSK343 on the cell viability and MT gene expression. A. The chemical structure of GSK343. B. HepG2 cells were treated with $0-20 \mu \mathrm{M}$ GSK343 for $72 \mathrm{~h}$. Cell viability was examined by MTT assay. C. HepG2 cells were treated with $10 \mu \mathrm{M}$ GSK343 for $6 \mathrm{~h}$. The mRNA expression of MT1 subtypes, MT2A, MT3 and MT4 was analyzed by real-time PCR. D. HepG2 cells were treated with $10 \mu \mathrm{M}$ GSK343 for $24 \mathrm{~h}$. The protein expression of MT1/MT2A was analyzed by western blot analysis. E. HepG2 cells were treated with $10 \mu \mathrm{M}$ GSK343 with or without $5 \mu \mathrm{M}$ TPEN for $24 \mathrm{~h}$. The protein expression of MT1/MT2A was analyzed by western blot analysis. F. HepG2 cells were treated with 0-20 $\mu \mathrm{M}$ GSK343 with or without $5 \mu \mathrm{M}$ TPEN for $72 \mathrm{~h}$. Cell viability was examined by MTT assay. 
(A)
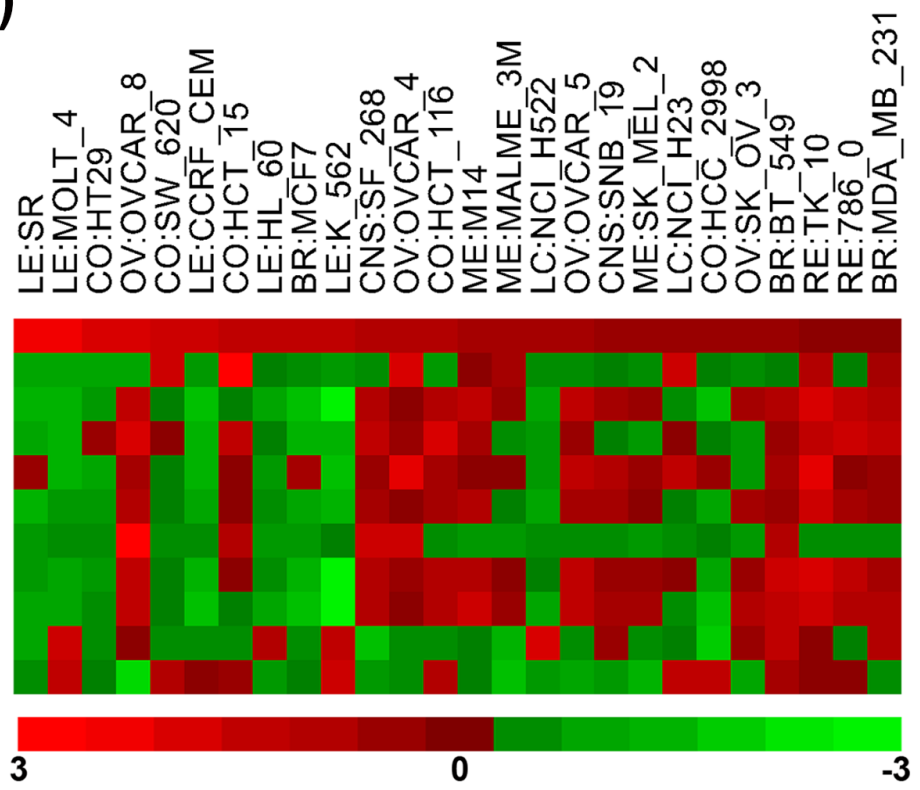

EZH2

MT1A

MT1B

MT1E

MT1F

MT1G

MT1M

MT1X

MT2A

MT3

MT4

\begin{tabular}{c}
\hline $\begin{array}{c}\text { Pearson's correlation } \\
\text { coefficient (vs. EZH2) }\end{array}$ \\
\hline-0.27 \\
-0.5 \\
-0.28 \\
-0.45 \\
-0.52 \\
0.1 \\
-0.49 \\
-0.46 \\
-0.04 \\
0.05 \\
\hline
\end{tabular}

3

$-3$

(B)

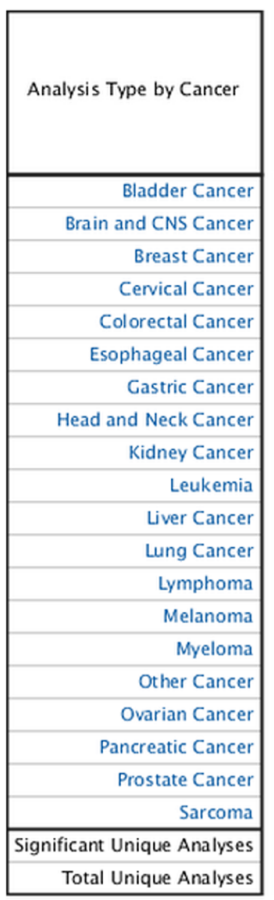

EZH2 MT1A MT1B MT1E MT1F MT1G MT1H MT1M MT1X MT2A

MT3 MT4

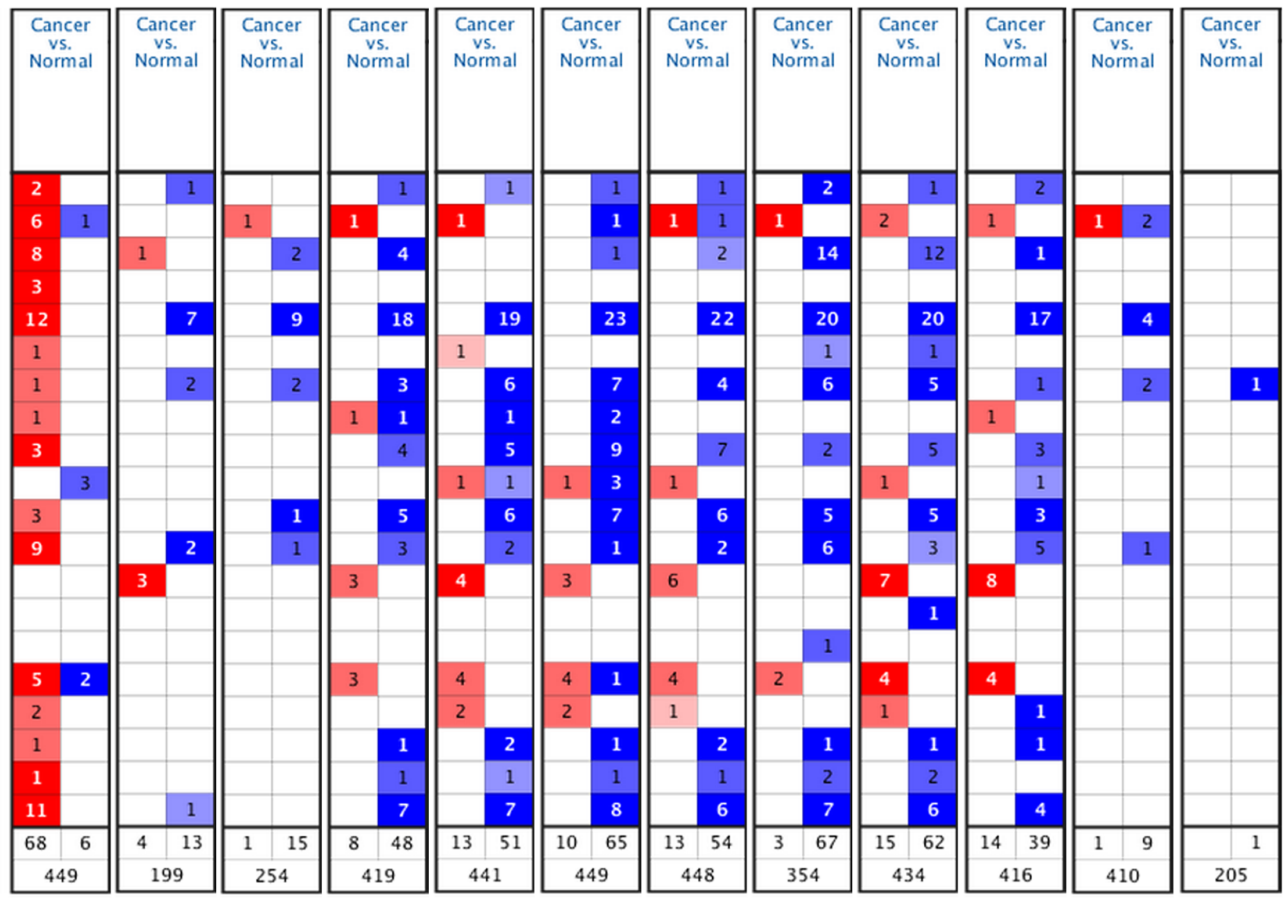

510
5

Figure 4: The correlation of EZH2 and MT genes in cell lines and cancer tissues. A. Left part: Heat map shows the relative expression level of EZH2, MT1 genes, MT2A, MT3 and MT4 from 26 selected NCI-60 cell lines. Red square: increased expression; green square: decreased expression. Right part: Pearson's correlation between EZH2 and MT genes. Coefficient > 0: positive correlation. Coefficient $<0$ : negative correlation. Coefficient near 0 indicates no correlation between two genes. B. Summary view of EZH2 and MT gene expression profiles in human tumors using published human oncology microarray data (Oncomine, http://www.oncomine.org/). The number in each cell under "Cancer $v s$. Normal" corresponds to the amount of cancer types that contains a significantly different level of genes compared to normal corresponding tissue. Thresholds for significance are: fold expression $>2 ; p$-value $<0.05$ and ranking of gene in the analyses $>$ top $10 \%$. Red signifies the gene overexpression in the analyses; blue represents the gene underexpression. Intensity of color signifies the best rank of gene in those analyses. 
Table 3: The gene expression levels of EZH2 and MTs in HCC tumor tissues in three published microarray datasets

\begin{tabular}{|l|l|l|l|}
\hline Gene Symbol & $\begin{array}{l}\text { Fold Change } \\
\text { (Chen X et al.) }\end{array}$ & $\begin{array}{l}\text { Fold Change } \\
\text { (Patil MA et al.) }\end{array}$ & $\begin{array}{l}\text { Fold Change } \\
\text { (Chen YL et al. })\end{array}$ \\
\hline EZH2 & 1.924 & 1.952 & 2.565 \\
\hline MT1A & ND & ND & ND \\
\hline MT1B & -4.006 & ND & ND \\
\hline MT1E & -8.946 & ND & -3.262 \\
\hline MT1F & -11.149 & ND & -4.306 \\
\hline MT1G & ND & ND & -3.146 \\
\hline MT1H & -13.237 & ND & ND \\
\hline MT1M & ND & ND & -3.097 \\
\hline MT1X & -10.636 & ND & -3.359 \\
\hline MT2A & ND & ND & -2.303 \\
\hline MT3 & ND & ND & ND \\
\hline MT4 & ND & ND & -0.171 \\
\hline
\end{tabular}

by real-time PCR (Figure 3C). MT1 subtypes, except for MT1A and MT1F, were induced by GSK343. In addition, MT2A, but not MT3 and MT4, was also induced (Figure $3 \mathrm{C})$. In addition, the induction of MT1/MT2A protein expression was also validated by western blot analysis (Figure 3D).

MT expression can be induced by various types of factors, such as heavy metals (e.g. zinc, cadmium, nickel, copper, silver, and cobalt), glucocorticoids, alkylating agents, oxidizing agents, and inflammatory signals [38]. Our results showed for the first time that EZH2 inhibitors can induce MT expression. The induction of MT genes can be regulated by the metal-regulatory transcription factor MTF-1 through binding to the metal regulatory elements (MREs) on MT gene promoters [38]. Because the elevated zinc ion is required for the MRE-binding activity of MTF-1 [39], whether zinc ion is responsible for the GSK343-induced MT expression was investigated by using an zinc chelator, TPEN. As shown in Figure 3E, TPEN abolished GSK343-induced MT1/MT2A protein expression. In addition, TPEN rescued HepG2 cells from GSK343-induced cytotoxicity (Figure 3F). These results suggested that GSK343 may induced MT expression in a zinc-dependent manner, and the induction of MTs was associated with the anticancer activity of GSK343.

Recently, MT is thought to play a role in the pathogenesis of HCC [40]. Several MT1 subtypes, including MT1F, MT1G, MT1H, and MT1M, have been identified as tumor suppressor genes in a variety of cancers including HCC [41-46]. The expression of MT1G and MT1M is frequently silenced in HCC due to promoter hypermethylation [42, 43]. In contrast, 5-azacytidine, a DNA demethylating agent, can activate MTF-1 and induce MT expression [47, 48]. Because EZH2 can directly control DNA methylation through the recruitment of DNA methyltransferase (DNMT) to certain PRC2 target gene promoters [49], inhibition of EZH2 may activate MTF-1dependent MT induction.

\section{Negative association of EZH2 and MT genes in cell lines and cancer tissues}

To investigate the correlation of MTs and EZH2, the related expression levels of EZH2 and MT genes from 26 selected NCI-60 cell lines (average transcript intensity Z scores of EZH2 > 0.1) were retrieved from the CellMiner database (http://discover.nci.nih.gov/cellminer/) [50, 51]. Heat map and Pearson's correlation between EZH2 and MT genes showed the negative correlation between EZH2 and MT1 subtypes except for MT1M (Figure 4A). In addition, MT2A, but not MT3 and MT4, is also negatively correlated with EZH2 expression (Figure 4A), which was consistent with the results that GSK343 only induced mRNA expression of MT1 subtypes and MT2A (Figure 3C). To investigate the clinical relevance of EZH2 and MTs in cancers, we perform a pan-cancer analysis for the expressions of EZH2 and MT genes in normal and cancerous tissues by using a complete collection of human cancer microarray data (Oncomine Database, http://www. oncomine.org/) [26]. As shown in Figure 4B, EZH2 was frequently overexpressed in various cancer datasets (68 out of 449 analyses). Oppositely, MT1/MT2A, but not MT3/MT4, genes were frequently downregulated in cancer datasets, especially for MT1E (48 out of 419 analyses), MT1F (51 out of 441 analyses), MT1G (65 out of 449 analyses), MT1H (54 out of 448 analyses), MT1M (67 out of 354 analyses), MT1X (62 out of 434 analyses), and MT2A (39 out of 416 analyses). Therefore, these results suggest the negative association of EZH2 and MT1/MT2A in cancers including HCC. To further confirm the relationship between EZH2 and MTs in HCC, 
the expressions of MT genes were correlated with the level of EZH2 in three microarray datasets having both HCC and normal liver tissues [27-29]. Consistently, most MT1/MT2A genes were downregulated in two of these datasets, which was associated with higher expression of EZH2 (Table 3).

\section{CONCLUSION}

Our in silico analysis shows that $\mathrm{EZH} 2$ is an attractive molecular target for treating $\mathrm{HCC}$. Our in vitro study indicates that GSK343 is a potential anti-HCC agent. Microarray analysis finds that MT1 and MT2A genes are induced by GSK343, which is associated with its anticancer activity. In addition, negative association of EZH2 and MT1/MT2A expression is found in cancers including HCC. Therefore, we proposed that the reversion of these gene expressions profiles by GSK343 will provide therapeutic benefits. Taken together, these results demonstrate the therapeutic value of GSK343 for treating HCC through the induction of MT genes.

\section{MATERIALS AND METHODS}

\section{Materials}

MT1/MT2A and GAPDH antibodies were purchased form GeneTex (Hsinchu, Taiwan). Horseradish peroxidase-labeled goat anti-rabbit and anti-mouse secondary antibodies were purchased from Jackson ImmunoResearch (West Grove, PA, USA). DMEM medium, L-glutamine, sodium pyruvate, and AntibioticAntimycotic (penicillin G, streptomycin and amphotericin B) were purchased from Life Technologies (Gaithersburg, MD, USA). Fetal bovine serum (FBS) was purchased from GIBCO (Grand Island, NY, USA). GSK343 was purchased from Biovision (Mountain View, CA, USA). N,N,N',N'-tetrakis(2-pyridinylmethyl)-1,2-ethanediamine (TPEN) was purchased from Cayman Chemical (Ann Arbor, MI, USA). 3-(4,5-dimethylthiazol-2-yl)-2,5diphenyl tetrazolium bromide (MTT) and dimethyl sulfoxide (DMSO) were purchased from Sigma (St. Louis, MO, USA). Protease and phosphatase inhibitor cocktails were purchased from Roche (Indianapolis, IN, USA). Other chemicals or reagents not specified were purchased from OneStar Biotechnology (New Taipei City, Taiwan).

\section{Cell culture}

HepG2 cells were purchased from the Bioresources Collection and Research Center (BCRC), Food Industry Research and Development Institute (Hsinchu, Taiwan). Cells were cultured in DMEM medium supplemented with 10\% FBS, $1 \mathrm{mM}$ sodium pyruvate, 1\% L-glutamine, 1\%
Antibiotic-Antimycotic Solution, and incubated at $37^{\circ} \mathrm{C}$ in a humidified incubator containing 5\% CO2.

\section{Cell viability assay}

Cell viability was measured with an MTT assay. Cells were plated in 96-well plates and treated with drugs. After $72 \mathrm{~h}$ of incubation, $0.5 \mathrm{mg} / \mathrm{mL}$ of MTT was added to each well for an additional $4 \mathrm{~h}$. The blue MTT formazan precipitate was then dissolved in $200 \mu \mathrm{L}$ of DMSO. The absorbance at $550 \mathrm{~nm}$ was measured on a multiwell plate reader.

\section{Western blot analysis}

Cells were lysed in an ice-cold buffer containing $50 \mathrm{mM}$ Tris- $\mathrm{HCl}$ ( $\mathrm{pH} 7.5$ ), $150 \mathrm{mM} \mathrm{NaCl}, 1 \mathrm{mM} \mathrm{MgCl}$, 2 mM EDTA, 1\% NP-40, 10\% glycerol, 1 mM DTT, 1x protease inhibitor cocktail and $1 \mathrm{x}$ phosphatase inhibitor cocktail at $4{ }^{\circ} \mathrm{C}$ for $30 \mathrm{~min}$. Cell lysates were separated on a sodium dodecylsulfate (SDS)-polyacrylamide gel, and then transferred electrophoretically onto the Hybond-C Extra nitrocellulose membrane (GE Healthcare, Piscataway, NJ, USA). The membrane was pre-hybridized in $20 \mathrm{mM}$ Tris- $\mathrm{HCl}(\mathrm{pH} 7.5), 150 \mathrm{mM} \mathrm{NaCl}, 0.05 \%$ Tween-20 (TBST buffer), and 5\% skim milk for $1 \mathrm{~h}$, and then transferred to a solution containing $1 \%$ bovine serum albumin (BSA)/TBST and a primary antibody and incubated overnight at $4{ }^{\circ} \mathrm{C}$. After washing with the TBST buffer, the membrane was submerged in $1 \% \mathrm{BSA} /$ TBST containing a horseradish peroxidase-conjugated secondary antibody for $1 \mathrm{~h}$. The membrane was washed with TBST buffer, and then developed with an enhanced chemiluminescence (ECL) system (Perkin-Elmer, Boston, MA, USA) and exposed to x-ray film (Roche, Indianapolis, IN, USA).

\section{Microarray analysis and real-time PCR}

Total RNA was extracted from HepG2 cells that were treated with $10 \mu \mathrm{M}$ GSK343 for $6 \mathrm{~h}$. The mRNA profiles were analyzed using Human OneArray Plus (Phalanx Biotech, Hsinchu, Taiwan). Target genes were validated by real-time PCR. Total RNA was extracted by using TRIZOL reagent (Invitrogen, Carlsbad, CA, USA). The quantity of RNA samples was determined using NanoDrop ND-1000 (Thermo Scientific, Wilmington, DE, USA). RNA samples were reverse-transcribed for $120 \mathrm{~min}$ at $37^{\circ} \mathrm{C}$ with High Capacity cDNA Reverse Transcription Kit (Applied Biosystems, Foster City, CA, USA). Quantitative PCR was performed by the condition: $10 \mathrm{~min}$ at $95^{\circ} \mathrm{C}$, and 40 cycles of $15 \mathrm{sec}$ at $95^{\circ} \mathrm{C}, 1 \mathrm{~min}$ at $60^{\circ} \mathrm{C}$ using 2X Power SYBR Green PCR Master Mix (Applied Biosystems) and $200 \mathrm{nM}$ of forward and reverse primers. 
Each assay was run on an Applied Biosystems 7300 Real-Time PCR system in triplicates and expression foldchanges were derived using the comparative CT method, GAPDH gene as endogenous control and untreated control sample as calibrator. The sequences of the primers used in real-time PCR were 5'-CCCATGAGCTGTGCCAAGT-3' and 5'-TTCCAAGTTTGTGCAGGTCACT-3' for MT1A, 5'-GCCCAGGGCTGCATCTG-3' and 5'-TTCCAAGTTTGTGCAGGTCACT-3' for MT1B, 5'-GGCTCCATTCTGCTTTCCAA-3' and 5'-AGTGGCGCAAGAGCAGTTG-3' for MT1E, 5'-AGCGGCCGGCTGTTG-3' and 5'-AGAGACTGGACTTTCCAAGAGAGAAG-3'

for MT1F, 5'-CCTGTGCCGCTGGTGTCT-3' and 5'-TGCAGCCTTGGGCACACT-3' for MT1G, 5'-GGGCTGCATCTGCAAAGG-3' and 5'-TTACGTGTCATTCTGTTTTCATCTGA-3' for MT1H, 5'-CGCTCCATTTATCGCTTGAGA-3' and 5'-TGCAGGCGCAGGAGACA-3' for MT1M, 5'-GCTGCGTGTTTTCCTCTTGAT-3' and 5'-GAGCAGCAGCTCTTCTTGCA-3' for MT1X, 5'-GCCCAGGGCTGCATCTG-3' and 5'-TTTGTGGAAGTCGCGTTCTTT-3' for MT2A, 5'-CTGCCCCTGCCCTTCTG-3' and 5'-ACACAGTCCTTGGCACACTTCTC-3' for MT3, and 5'-GCAACTGTAAAACATGTCGGAAGA-3' and 5'-AGCCTCCTTTGCAGATGCA-3'.

\section{Statistical analysis}

Means and standard deviations of samples were calculated from the numerical data generated in this study. Data were analyzed using Student's $t$ test. $p$ values $<0.05$ $\left.{ }^{*}\right)$ were considered significant.

\section{CONFLICTS OF INTEREST}

The authors declare that there is no conflict of interest.

\section{FUNDING}

This work was supported by research grants from Taiwan's Ministry of Science and Technology (MOST1042320-B-038-005 to PMY), Taipei Medical University (TMU103-AE2-I04-4 and TMU104-AE2-I02-4 to PMY), Taipei Medical University - Shuang Ho Hospital (104TMU-SHH-03 to PMY), and Mackay Memorial Hospital (MMH-104-027 to TPL). This work was also in part supported by Taiwan's Ministry of Health and Welfare (MOHW103-TD-B-111-01, MOHW103TDU-B-212-113001, MOHW103-TDU-212-114006, and MOHW104-TDU-B-212-124-001), and the Health and welfare surcharge of tobacco products.

\section{REFERENCES}

1. Roberts LR and Gores GJ. Hepatocellular carcinoma: molecular pathways and new therapeutic targets. Semin Liver Dis. 2005; 25: 212-25.

2. Parkin DM, Bray F, Ferlay J and Pisani P. Estimating the world cancer burden: Globocan 2000. Int J Cancer. 2001; 94: 153-6.

3. Llovet JM, Ricci S, Mazzaferro V, Hilgard P, Gane E, Blanc JF, de Oliveira AC, Santoro A, Raoul JL, Forner A, Schwartz M, Porta C, Zeuzem S, et al. Sorafenib in advanced hepatocellular carcinoma. N Engl J Med. 2008; 359: 378-90.

4. Cheng AL, Kang YK, Chen Z, Tsao CJ, Qin S, Kim JS, Luo R, Feng J, Ye S, Yang TS, Xu J, Sun Y, Liang H, et al. Efficacy and safety of sorafenib in patients in the AsiaPacific region with advanced hepatocellular carcinoma: a phase III randomised, double-blind, placebo-controlled trial. Lancet Oncol. 2009; 10: 25-34.

5. Kleer CG, Cao Q, Varambally S, Shen R, Ota I, Tomlins SA, Ghosh D, Sewalt RG, Otte AP, Hayes DF, Sabel MS, Livant D, Weiss SJ, et al. EZH2 is a marker of aggressive breast cancer and promotes neoplastic transformation of breast epithelial cells. Proc Natl Acad Sci U S A. 2003; 100: 11606-11.

6. Raaphorst FM, Meijer CJ, Fieret E, Blokzijl T, Mommers E, Buerger H, Packeisen J, Sewalt RA, Otte AP and van Diest PJ. Poorly differentiated breast carcinoma is associated with increased expression of the human polycomb group EZH2 gene. Neoplasia. 2003; 5: 481-8.

7. Varambally S, Dhanasekaran SM, Zhou M, Barrette TR, Kumar-Sinha C, Sanda MG, Ghosh D, Pienta KJ, Sewalt RG, Otte AP, Rubin MA and Chinnaiyan AM. The polycomb group protein EZH2 is involved in progression of prostate cancer. Nature. 2002; 419: 624-9.

8. Croonquist PA and Van Ness B. The polycomb group protein enhancer of zeste homolog 2 (EZH 2) is an oncogene that influences myeloma cell growth and the mutant ras phenotype. Oncogene. 2005; 24: 6269-80.

9. Tan J, Yang X, Zhuang L, Jiang X, Chen W, Lee PL, Karuturi RK, Tan PB, Liu ET and Yu Q. Pharmacologic disruption of Polycomb-repressive complex 2-mediated gene repression selectively induces apoptosis in cancer cells. Genes Dev. 2007; 21: 1050-63.

10. Tan JZ, Yan Y, Wang XX, Jiang Y and Xu HE. EZH2: biology, disease, and structure-based drug discovery. Acta Pharmacol Sin. 2014; 35: 161-74.

11. Knutson SK, Wigle TJ, Warholic NM, Sneeringer CJ, Allain CJ, Klaus CR, Sacks JD, Raimondi A, Majer CR, Song J, Scott MP, Jin L, Smith JJ, et al. A selective inhibitor of EZH2 blocks H3K27 methylation and kills mutant lymphoma cells. Nat Chem Biol. 2012; 8: 890-6.

12. McCabe MT, Ott HM, Ganji G, Korenchuk S, Thompson C, Van Aller GS, Liu Y, Graves AP, Della Pietra A, 3rd, Diaz 
E, LaFrance LV, Mellinger M, Duquenne C, et al. EZH2 inhibition as a therapeutic strategy for lymphoma with EZH2-activating mutations. Nature. 2012; 492: 108-12.

13. Qi W, Chan H, Teng L, Li L, Chuai S, Zhang R, Zeng J, Li M, Fan H, Lin Y, Gu J, Ardayfio O, Zhang JH, et al. Selective inhibition of Ezh2 by a small molecule inhibitor blocks tumor cells proliferation. Proc Natl Acad Sci U S A. 2012; 109: 21360-5.

14. Verma SK, Tian X, LaFrance LV, Duquenne C, Suarez DP, Newlander KA, Romeril SP, Burgess JL, Grant SW, Brackley JA, Graves AP, Scherzer DA, Shu A, et al. Identification of Potent, Selective, Cell-Active Inhibitors of the Histone Lysine Methyltransferase EZH2. ACS Med Chem Lett. 2012; 3: 1091-6.

15. Chen YL, Wang TH, Hsu HC, Yuan RH and Jeng YM. Overexpression of CTHRC1 in hepatocellular carcinoma promotes tumor invasion and predicts poor prognosis. PLoS One. 2013; 8: e70324.

16. Patil MA, Chua MS, Pan KH, Lin R, Lih CJ, Cheung ST, Ho C, Li R, Fan ST, Cohen SN, Chen X and So S. An integrated data analysis approach to characterize genes highly expressed in hepatocellular carcinoma. Oncogene. 2005; 24: 3737-47.

17. Chen X, Cheung ST, So S, Fan ST, Barry C, Higgins J, Lai KM, Ji J, Dudoit S, Ng IO, Van De Rijn M, Botstein $\mathrm{D}$ and Brown PO. Gene expression patterns in human liver cancers. Mol Biol Cell. 2002; 13: 1929-39.

18. Warde-Farley D, Donaldson SL, Comes O, Zuberi K, Badrawi R, Chao P, Franz M, Grouios C, Kazi F, Lopes CT, Maitland A, Mostafavi S, Montojo J, et al. The GeneMANIA prediction server: biological network integration for gene prioritization and predicting gene function. Nucleic Acids Res. 2010; 38(Web Server issue): W214-20.

19. Ladu S, Calvisi DF, Conner EA, Farina M, Factor VM and Thorgeirsson SS. E2F1 inhibits c-Myc-driven apoptosis via PIK3CA/Akt/mTOR and COX-2 in a mouse model of human liver cancer. Gastroenterology. 2008; 135: 1322-32.

20. Wong N, Yeo W, Wong WL, Wong NL, Chan KY, Mo FK, Koh J, Chan SL, Chan AT, Lai PB, Ching AK, Tong JH, $\mathrm{Ng} \mathrm{HK}$, et al. TOP2A overexpression in hepatocellular carcinoma correlates with early age onset, shorter patients survival and chemoresistance. Int J Cancer. 2009; 124: 64452.

21. Chen S, Bohrer LR, Rai AN, Pan Y, Gan L, Zhou X, Bagchi A, Simon JA and Huang H. Cyclin-dependent kinases regulate epigenetic gene silencing through phosphorylation of EZH2. Nat Cell Biol. 2010; 12: 1108-14.

22. Cheng AS, Lau SS, Chen Y, Kondo Y, Li MS, Feng H, Ching AK, Cheung KF, Wong HK, Tong JH, Jin H, Choy $\mathrm{KW}$, Yu J, et al. EZH2-mediated concordant repression of Wnt antagonists promotes beta-catenin-dependent hepatocarcinogenesis. Cancer Res. 2011; 71: 4028-39.

23. Sasaki M, Ikeda H, Itatsu K, Yamaguchi J, Sawada S,
Minato H, Ohta T and Nakanuma Y. The overexpression of polycomb group proteins Bmil and EZH2 is associated with the progression and aggressive biological behavior of hepatocellular carcinoma. Lab Invest. 2008; 88: 873-82.

24. Sudo T, Utsunomiya T, Mimori K, Nagahara H, Ogawa $\mathrm{K}$, Inoue $\mathrm{H}$, Wakiyama S, Fujita $\mathrm{H}$, Shirouzu K and Mori M. Clinicopathological significance of EZH2 mRNA expression in patients with hepatocellular carcinoma. Br J Cancer. 2005; 92: 1754-8.

25. Chen Y, Lin MC, Yao H, Wang H, Zhang AQ, Yu J, Hui CK, Lau GK, He ML, Sung J and Kung HF. Lentivirus-mediated RNA interference targeting enhancer of zeste homolog 2 inhibits hepatocellular carcinoma growth through downregulation of stathmin. Hepatology. 2007; 46: 200-8.

26. Rhodes DR, Kalyana-Sundaram S, Mahavisno V, Varambally R, Yu J, Briggs BB, Barrette TR, Anstet MJ, Kincead-Beal C, Kulkarni P, Varambally S, Ghosh D and Chinnaiyan AM. Oncomine 3.0: genes, pathways, and networks in a collection of 18,000 cancer gene expression profiles. Neoplasia. 2007; 9: 166-80.

27. Guichard C, Amaddeo G, Imbeaud S, Ladeiro Y, Pelletier L, Maad IB, Calderaro J, Bioulac-Sage P, Letexier M, Degos F, Clement B, Balabaud C, Chevet E, et al. Integrated analysis of somatic mutations and focal copy-number changes identifies key genes and pathways in hepatocellular carcinoma. Nat Genet. 2012; 44: 694-8.

28. Roessler S, Jia HL, Budhu A, Forgues M, Ye QH, Lee JS, Thorgeirsson SS, Sun Z, Tang ZY, Qin LX and Wang XW. A unique metastasis gene signature enables prediction of tumor relapse in early-stage hepatocellular carcinoma patients. Cancer Res. 2010; 70: 10202-12.

29. Wurmbach E, Chen YB, Khitrov G, Zhang W, Roayaie S, Schwartz M, Fiel I, Thung S, Mazzaferro V, Bruix J, Bottinger E, Friedman S, Waxman S, et al. Genomewide molecular profiles of $\mathrm{HCV}$-induced dysplasia and hepatocellular carcinoma. Hepatology. 2007; 45: 938-47.

30. Ponten F, Jirstrom K and Uhlen M. The Human Protein Atlas - a tool for pathology. J Pathol. 2008; 216: 387-93.

31. Uhlen M, Bjorling E, Agaton C, Szigyarto CA, Amini B, Andersen E, Andersson AC, Angelidou P, Asplund A, Asplund C, Berglund L, Bergstrom K, Brumer H, et al. A human protein atlas for normal and cancer tissues based on antibody proteomics. Mol Cell Proteomics. 2005; 4: 192032.

32. Uhlen M, Fagerberg L, Hallstrom BM, Lindskog C, Oksvold P, Mardinoglu A, Sivertsson A, Kampf C, Sjostedt E, Asplund A, Olsson I, Edlund K, Lundberg E, et al. Proteomics. Tissue-based map of the human proteome. Science. 2015; 347: 1260419.

33. Uhlen M, Oksvold P, Fagerberg L, Lundberg E, Jonasson K, Forsberg M, Zwahlen M, Kampf C, Wester K, Hober $\mathrm{S}$, Wernerus $\mathrm{H}$, Bjorling L and Ponten F. Towards a knowledge-based Human Protein Atlas. Nat Biotechnol. 2010; 28: 1248-50. 
34. Berglund L, Bjorling E, Oksvold P, Fagerberg L, Asplund A, Szigyarto CA, Persson A, Ottosson J, Wernerus H, Nilsson P, Lundberg E, Sivertsson A, Navani S, et al. A genecentric Human Protein Atlas for expression profiles based on antibodies. Mol Cell Proteomics. 2008; 7: 201927.

35. Knutson SK, Warholic NM, Wigle TJ, Klaus CR, Allain CJ, Raimondi A, Porter Scott M, Chesworth R, Moyer MP, Copeland RA, Richon VM, Pollock RM, Kuntz KW, et al. Durable tumor regression in genetically altered malignant rhabdoid tumors by inhibition of methyltransferase EZH2. Proc Natl Acad Sci U S A. 2013; 110: 7922-7.

36. Babula P, Masarik M, Adam V, Eckschlager T, Stiborova M, Trnkova L, Skutkova H, Provaznik I, Hubalek J and Kizek R. Mammalian metallothioneins: properties and functions. Metallomics. 2012; 4: 739-50.

37. Thirumoorthy N, Shyam Sunder A, Manisenthil Kumar K, Senthil Kumar M, Ganesh G and Chatterjee M. A review of metallothionein isoforms and their role in pathophysiology. World J Surg Oncol. 2011; 9: 54.

38. Haq F, Mahoney M and Koropatnick J. Signaling events for metallothionein induction. Mutat Res. 2003; 533: 211-26.

39. Bittel D, Dalton T, Samson SL, Gedamu L and Andrews GK. The DNA binding activity of metal response elementbinding transcription factor-1 is activated in vivo and in vitro by zinc, but not by other transition metals. J Biol Chem. 1998; 273: 7127-33.

40. Nagamine $T$ and Nakajima $K$. Significance of Metallothionein Expression in Liver Disease. Curr Pharm Biotechnol. 2013.

41. Ferrario C, Lavagni P, Gariboldi M, Miranda C, Losa M, Cleris L, Formelli F, Pilotti S, Pierotti MA and Greco A. Metallothionein $1 \mathrm{G}$ acts as an oncosupressor in papillary thyroid carcinoma. Lab Invest. 2008; 88: 474-81.

42. Kanda M, Nomoto S, Okamura Y, Nishikawa Y, Sugimoto H, Kanazumi N, Takeda S and Nakao A. Detection of metallothionein $1 \mathrm{G}$ as a methylated tumor suppressor gene in human hepatocellular carcinoma using a novel method of double combination array analysis. Int J Oncol. 2009; 35: 477-83.

43. Mao J, Yu H, Wang C, Sun L, Jiang W, Zhang P, Xiao Q, Han D, Saiyin H, Zhu J, Chen T, Roberts LR, Huang H, et al. Metallothionein MT1M is a tumor suppressor of human hepatocellular carcinomas. Carcinogenesis. 2012; 33: 256877.

44. Fu J, Lv H, Guan H, Ma X, Ji M, He N, Shi B and Hou P. Metallothionein $1 \mathrm{G}$ functions as a tumor suppressor in thyroid cancer through modulating the PI3K/Akt signaling pathway. BMC Cancer. 2013; 13: 462.

45. Han YC, Zheng ZL, Zuo ZH, Yu YP, Chen R, Tseng GC, Nelson JB and Luo JH. Metallothionein $1 \mathrm{~h}$ tumour suppressor activity in prostate cancer is mediated by euchromatin methyltransferase 1. J Pathol. 2013; 230: 18493.
46. Yan DW, Fan JW, Yu ZH, Li MX, Wen YG, Li DW, Zhou CZ, Wang XL, Wang Q, Tang HM and Peng $\mathrm{ZH}$. Downregulation of metallothionein $1 \mathrm{~F}$, a putative oncosuppressor, by loss of heterozygosity in colon cancer tissue. Biochim Biophys Acta. 2012; 1822: 918-26.

47. Ghoshal K, Datta J, Majumder S, Bai S, Dong X, Parthun $\mathrm{M}$ and Jacob ST. Inhibitors of histone deacetylase and DNA methyltransferase synergistically activate the methylated metallothionein I promoter by activating the transcription factor MTF-1 and forming an open chromatin structure. Mol Cell Biol. 2002; 22: 8302-19.

48. Ghoshal K, Majumder S, Li Z, Dong X and Jacob ST. Suppression of metallothionein gene expression in a rat hepatoma because of promoter-specific DNA methylation. J Biol Chem. 2000; 275: 539-47.

49. Vire E, Brenner C, Deplus R, Blanchon L, Fraga M, Didelot C, Morey L, Van Eynde A, Bernard D, Vanderwinden JM, Bollen M, Esteller M, Di Croce L, et al. The Polycomb group protein EZH2 directly controls DNA methylation. Nature. 2006; 439: 871-4.

50. Reinhold WC, Sunshine M, Liu H, Varma S, Kohn KW, Morris J, Doroshow J and Pommier Y. CellMiner: a webbased suite of genomic and pharmacologic tools to explore transcript and drug patterns in the NCI-60 cell line set. Cancer Res. 2012; 72: 3499-511.

51. Shankavaram UT, Varma S, Kane D, Sunshine M, Chary KK, Reinhold WC, Pommier $\mathrm{Y}$ and Weinstein JN. CellMiner: a relational database and query tool for the NCI60 cancer cell lines. BMC Genomics. 2009; 10: 277. 